\title{
Comprehensive proteomic profiling of adult Angiostrongylus costaricensis, a human parasitic nematode
}

\author{
Karina M. Rebello ${ }^{a, b, d}$, Juliana S.L. Barros ${ }^{a, b}$, Ester M. Mota ${ }^{b}$, Paulo C. Carvalho ${ }^{a, c, d}$, \\ Jonas Perales ${ }^{a, d}$, Henrique L. Lenzi ${ }^{b}$, Ana G.C. Neves-Ferreira ${ }^{a, d, *}$ \\ ${ }^{a}$ Toxinology Laboratory, Oswaldo Cruz Institute (IOC), Fiocruz, Rio de Janeiro, Brazil \\ ${ }^{\mathrm{b}}$ Pathology Laboratory, Oswaldo Cruz Institute (IOC), Fiocruz, Rio de Janeiro, Brazil \\ ${ }^{c}$ Center for Technological Development in Health (CDTS), Fiocruz, Rio de Janeiro, Brazil \\ ${ }^{\mathrm{d}}$ Rio de Janeiro Proteomic Network, Brazil
}

\section{A R T I C L E I N F O}

Available online 10 May 2011

Keywords:

Angiostrongylus costaricensis

Nematode

Proteome

Immunogenic proteins

\begin{abstract}
A B S T R A C T
Angiostrongylus costaricensis is a nematode helminth that causes an intestinal acute inflammatory process known as abdominal angiostrongyliasis, which is a poorly understood human disease occurring in Latin America. Our aim was to study the proteomic profiles of adult parasites focusing on immunogenic proteins. Total cellular extracts from both genders showed similar 2-DE profiles, with $60 \%$ of all protein spots focused between $\mathrm{pH} 5-7$ and presenting molecular masses from 20.1 to $66 \mathrm{kDa}$. A total of 53 different dominant proteins were identified in our dataset and were mainly associated with the following over-represented Gene Ontology Biological Process terms: "macromolecule metabolic process", "developmental process", "response to stress", and "biological regulation". Female and male immunoblots showed similar patterns of reactive proteins. Immunoreactive spots identified by MALDI-PSD were found to represent heat shock proteins, a putative abnormal DAuer Formation family member, and galectins. To date, very few biochemical analyses have focused on the nematode Angiostrongylus costaricensis. As such, our results contribute to a better understanding of its biology and the mechanisms underlying the host-parasite relationship associated with this species. Moreover, our findings represent a first step in the search for candidate proteins for diagnostic assays and the treatment of this parasitic infection.
\end{abstract}

(c) 2011 Elsevier B.V. All rights reserved.

\section{Introduction}

There are 15 Angiostrongylus species, of which only two represent a public health concern related to causing abdominal angiostrongyliasis and eosinophilic meningoencephalitis in humans: A. costaricensis and A. cantonensis, respectively [1,2]. A. cantonensis, a rat lungworm, frequently occurs in outbreaks with case numbers ranging from tens to hundreds [3]. Cases have been detected throughout Southeast Asia, the South Pacific, Madagascar, Africa, the Caribbean, and the continents of Australia and North America [4,5]. Over 2827 cases of A. cantonensis meningitis have been reported in approximately 30 countries [3,4]. This species was recently also detected in Brazil [6,7]. Additionally, A. costaricensis produces abdominal angiostrongyliasis; its biological cycle was described by Morera (1973) [8] (Fig. 1). This disease was first described in Costa Rica [9]; other cases have been reported from the United States to northern Argentina [10]. Although this infection is enzootic in Texas [11], the only case of autochthonous human infection reported in the United States [12] was later identified

\footnotetext{
* Corresponding author at: Laboratório de Toxinologia, Pavilhão Ozório de Almeida, Instituto Oswaldo Cruz, Fiocruz. Av. Brasil, 4365 Manguinhos, 21040-900 Rio de Janeiro, Brazil. Tel.: +55 212562 1381; fax: +55 2125621410.

E-mail address: anag@ioc.fiocruz.br (A.G.C. Neves-Ferreira).
} 


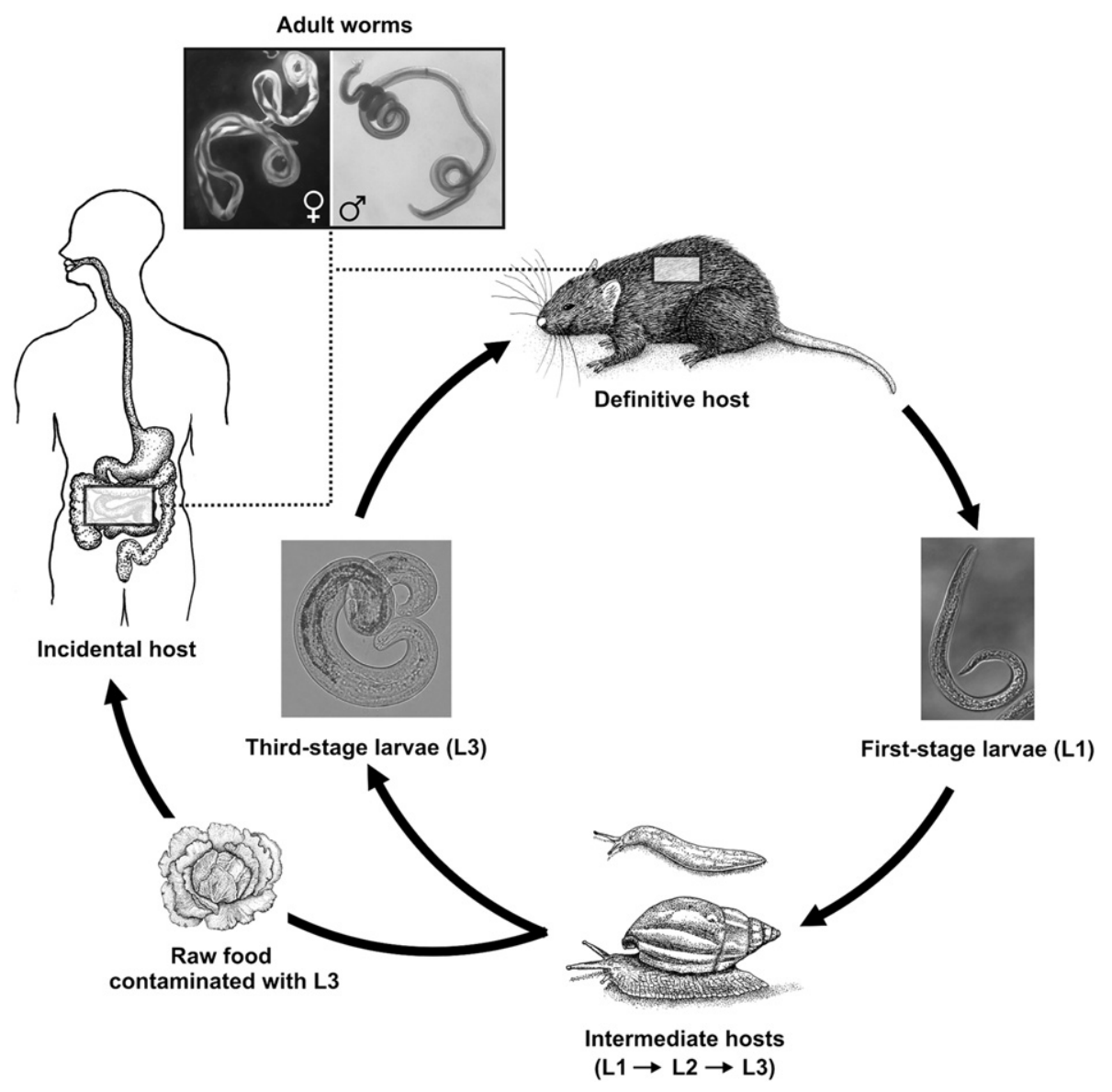

Fig. 1 - The biological life cycle of Angiostrongylus costaricensis. A. costaricensis is normally found in Sigmodon hispidus, Rattus rattus and other definitive hosts. The first stage larvae (L1) in the definitive hosts migrate into the intestinal lumen and are eliminated with the feces. Mollusks eat the contaminated feces or are externally infected via their epidermis, and second (L2) and third stage larvae (L3) develop in these hosts. The L3 are infectious to both definitive hosts and humans, who are incidental hosts. Infection with these parasites occurs through the ingestion of infected mollusks or unwashed vegetables contaminated with mucous of mollusks containing L3 A. costaricensis (see the Introduction for more details).

as a case of anisakiasis; however the authors replied maintaining the original diagnosis [13]. Even though abdominal angiostrongyliasis has been considered a public health problem in Costa Rica, its first reported outbreak occurred in Guatemala, where raw mint (eaten separately or as an ingredient in ceviche) was the likely vehicle of infection [14].

Several rodents are known to be definitive hosts of A. costaricensis, whereas its intermediate hosts are represented by mollusks of the Veronicellidae family [15]. More recently, it was shown that dogs can act as a reservoir host for A. costaricensis [16]. The parasite spreads to humans by means of the consumption of raw vegetables containing third-stage larvae (L3) developed in mollusks [17]. Currently, the explosive expansion of the giant snail Achatina fulica in many areas of Brazil has the potential to increase the transmission of A. costaricensis and A. cantonensis throughout the entire country [18-20]. A low number of infective L3 are apparently required to establish infection in vertebrate hosts, including humans [21]. According to serological studies, the number of clinical cases may be higher than the number of cases presenting symptomatic disease [22]. As shown by a preliminary evaluation, the antibody response to these in- fections gradually decreases over time, indicating that the worms do not survive for a long period in humans [23,24]. These observations suggest that abdominal angiostrongyliasis can spontaneously recede and should be better substantiated with a more sensitive and specific serum diagnostic test due to the existence of broad cross-reactivity among helminths of different species. Unfortunately, attempts to increase the specificity of immunodiagnostic tests usually lead to lower sensitivity, and vice-versa [23]. More extensive observations with clinical, parasitological and serological follow-ups are required for better evaluation of the prognostic value of serological and other molecular methods associated with abdominal angiostrongyliasis [24]. It is of note that some patients develop a severe abdominal disease that is only cured by surgery that removes the affected intestinal segment. The adult worms tend to aggregate in the more affected areas, and patients can be cured with this surgery. Longitudinal studies have not yet been performed due to the limitations of diagnostic tests and the inefficacy of antiparasitic drugs. In conclusion, abdominal angiostrongyliasis is clearly an underdiagnosed disease [25]. Better knowledge about the distribution of this human infection will depend on awareness of the 
disease among medical personnel, on epidemiologic surveys of the infection in regional mollusk populations and on reliable serological tests based on well-defined antigens that are still not available [22-28]. Pathologists should be on constant alert during histopathological analysis of cecal appendix and intestinal segments with intense eosinophilia; a detailed analysis can sometimes reveal eggs, vasculitis and even adult worms in unexpected material [29].

The nematode species comprising the genus Angiostrongylus were initially grouped into two subgenera, Angiostrongylus and Parastrongylus; these two subgenera have been elevated to full genera status [30,31], but this taxonomic treatment has not been generally accepted [2]. Certain Angiostrongylus species, such as A. cantonensis, A. costaricensis, A. dujardini and A. malaysiensis, have been recategorized [31] as belonging to the genus Parastrongylus [32] based on differences in the morphology of the parasite male bursa and the final mammalian host [33]. All phylogenetic analyses that have been carried out to date do not support the assignment of the component species to two genera or subgenera, i.e., Angiostrongylus and Parastrongylus [2]. More recently, a molecular analysis using restriction fragment length polymorphisms (RFLPs) allowed the differentiation of $\mathrm{A}$. cantonensis, A. costaricensis and A. vasorum [34]. The molecular differentiation and phylogenetic trees of Angiostrongylus species have been defined based on sequences from small-subunit ribosomal DNA [33], internal transcribed spacer 2 (ITS-2)[35], mitochondrial cytochrome-c oxidase subunit (COI) [2] and a $66-\mathrm{kDa}$ protein gene of A. cantonensis [36]. Based on COI sequences and the $66-\mathrm{kDa}$ protein gene of A. cantonensis, two major clades were defined: (1) A. cantonensis and A. malaysiensis, and (2) A. costaricensis and A. vasorum [2,36]. In the study based on COI analysis, a Costa Rican isolate of A. costaricensis was found to be quite different from a Brazilian isolate, with an uncorrected p-distance of $11.39 \%$. The COI and ITS-2 results indicate the possibility that the Costa Rica and Brazil isolates could be cryptic species [2,35]. In both maximum-parsimony and maximum-likelihood analyses, A. costaricensis was found to be the most distant taxon and possibly to represent the earliest divergence group in evolutionary history [36].

Our group $[37,38]$ showed the life cycle of A. costaricensis in its natural vertebrate host (Sigmodon hispidus) and in a mouse model to be much more complex than originally described by Morera [8]. These studies have revealed that the L3 stage alternatively goes through two migratory courses during its development into an adult worm: a lymphatic/venous-arterial pathway and a venous portal pathway. The former is considered to represent the primary pathway because it is used by most of the larvae. Like other metastrongylides, A. costaricensis passes over the pulmonary circulation to migrate from the lymphatic system to the arterial circulation, where they circulate for some days before reaching their definitive habitat in the mesenteric arteries of the terminal ileum and cecum. Oviposition by mature females begins 15 days after this and defines two important periods from the pathological point of view: pre- and post-oviposition. The former depends on worms in different stages of development, and the latter essentially depends on egg deposition in tissues.

Due to the disease characteristics associated with these nematodes, the incubation period in humans is highly variable; it can range from 14 days [39] to approximately 49-79 days [40] and even to more than one year [41].The main clinical signs and symptoms of the disease are also variable and include palpable abdominal masses (tumor-like masses), abdominal pain and rigidity, fever, anorexia, vomiting, diarrhea, intestinal obstipation, hepatomegaly, jaundice, abdominal distension, emaciation, unproductive cough, nausea, intestinal obstruction, perforation or bleeding and painful rectal examination. The radiologic findings related to the disease are intestinal dilatation or obstruction, hydro-air levels, tumor-like masses, intestinal wall thickening and rigidity and spasticity of the intestinal wall. Leukograms usually present leukocytosis with eosinophilia (>10-70\%). The main areas of localization of the lesions are in the cecum, ascending colon, appendix, and small intestine $[14,42-44]$. Some cases can essentially evolve with hepatic lesions, such as nodules or focal necrosis [45-48], which are partially explained by the secondary portal pathway $[37,38]$. Using two different animal models (Swiss Webster mice and Sigmodon hispidus rats), we showed that during its life cycle, A. costaricensis presents an alternative migration to hepatic veins as a normal event in the venous portal pathway, in which the nematode matures and lays fertile eggs inside the liver. A. costaricensis adult worms can then reach the liver through branches of the hepatic artery and portal vein.

The proportion of cases that are oligosymptomatic or asymptomatic is unknown, and abdominal angiostrongyliasis appears not to always represent a persistent infection [22,44]. The mortality rate among symptomatic cases ranges from 1.8 to $7.4 \%[14,44]$. It is important to note that even in the preoviposition phase, vascular lesions were observed to occur in S. hispidus expressed as an inflammatory reaction in the abdominal lymphatic circulation (lymphangitis and perilymphangitis constituted by macrophages, eosinophils, and neutrophils) and periarteritis with or without fibrosis, fibrinoid necrosis of the muscular layer, and micro-hemorrhages in the arterial wall [38]. These events could explain some rare human cases with a short incubation period. The diagnosis of abdominal angiostrongyliasis is confirmed by the identification of eggs, larva, or adult worms of A. costaricensis in surgical specimens [48]. Larvogenesis is not a frequent event in human cases and the eggs are sometimes limited to the morula stage.

A comparative histopathological study of confirmed and suspected cases of A. costaricensis infection revealed two types of macroscopic features: a predominant thickening of the intestinal wall (pseudoneoplastic pattern) and congestive necrotic lesions (ischemic-congestive pattern). Microscopically, three fundamental histopathological findings were detected, defining a triplet that establishes the diagnosis of probable abdominal angiostrongyliasis: (1) a massive infiltration of eosinophils in all layers of the intestinal wall; (2) a granulomatous reaction; and (3) eosinophilia vasculitis affecting arteries, veins, lymphatic structures and capillaries. The eosinophilic arteritis is usually centripetal, originating in the adventitia [44]. A definitive diagnosis relies on the identification of adult worms in arterial vessels (more rarely in veins) following surgical intervention (Fig. 2A-F). No treatment has thus far proven to be effective against the disease; moreover, treatment with some antiparasitic drugs can even worsen the course of the disease through unknown mechanisms [10]. Recently, it was shown that intranasal vaccination against 

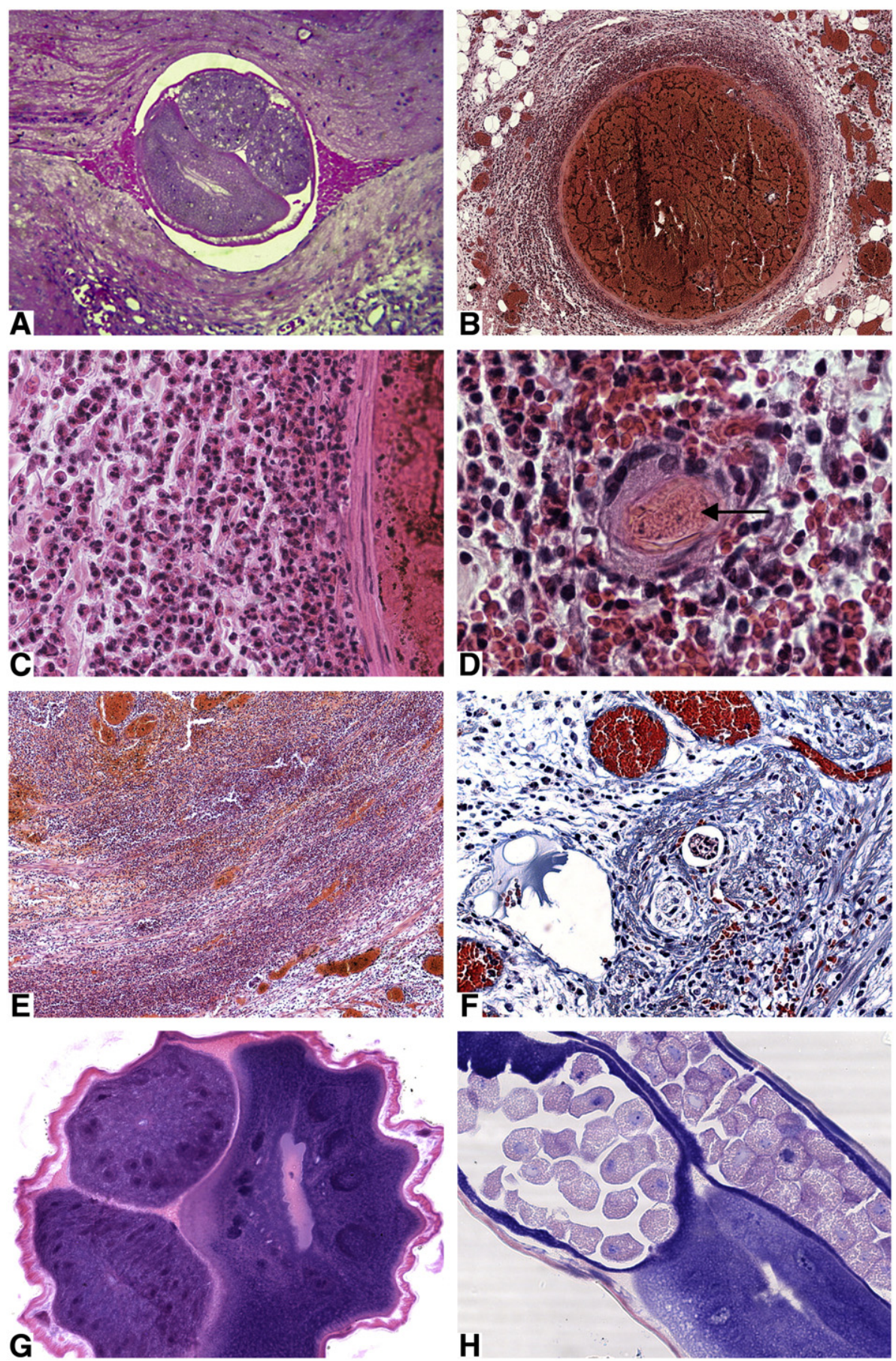

Fig. 2 - Histological lesions of abdominal angiostrongyliasis caused by Angiostrongylus costaricensis. (A) Female adult worm in a mesenteric artery of an infected Sigmodon hispidus individual showing the intestine (on the left) and the two ovaries (on the right).The parasite is located in the interface between the arterial endothelial layer and a thrombus [Hematoxylin-eosin (HE) 80x]. (B) Eosinophilic periarteritis with thrombus on human cecal appendix (HE 10x). (C) Detail of eosinophilic periarteritis full of eosinophils (HE 63x). (D) Immature egg (arrow head) in a human cecal wall, surrounded by a giant cell in the middle of the inflammatory infiltrate (HE 100x). (E) Injury of a human cecal muscle layer by intense inflammatory infiltrate (HE 10x). (F) Eggs in morula stage surrounded by inflammatory cells in a human cecal subserosa layer; the blood vessels are dilated and congested (Masson's trichrome stain 10x). (G) Transversal section of an isolated female adult worm surrounded by a clear muscle layer under the cuticle; the structure on the right is the intestine with its central lumen, and on the left, two anterior ovaries (immature segment) can be observed (Lennert's Giemsa 63x). (H) Longitudinal section of an isolated female adult worm presenting the two uteri full of eggs; the darker structure corresponds to the intestine (Lennert's Giemsa 40x). 
A. costaricensis with synthetic antigens and recombinant peptides belonging to the catalytic region of the serine/ threonine phosphatase 2A (PP2a) protein of the parasite results in a protective immune response in $\mathrm{C57Bl} / 6$ mice [49].

Even though nematodes are one of the most numerous and diverse phyla of animals on earth, including several human parasitic helminths, few studies have employed proteomic approaches to study their biology. One of the main limitations to performing such studies is the scarcity of genomic information available, which may hamper faster progress in this area [50]. In addition to the model organisms Caenorhabditis elegans [51] and C. briggsae [52], only five nuclear genomes from nematodes have been published: Brugia malayi [53], a major human filarial parasite; Meloidogyne incognita [54] and M. hapla [55], plant pathogens; Pristionchus pacificus [56], a beetle-associated species used as a model system in evolutionary biology; and Trichinella spiralis [57], a food-borne zoonotic parasite.

Most of the proteomic studies on nematodes have been performed on the free-living soil worm C. elegans, which is a convenient model system for in vivo studies of various physiological problems relevant to human diseases. Proteomics has contributed to the characterization of $C$. elegans nematodes by improving genome annotation and allowing analyses of phenotypic changes following RNAi treatment (targeted gene suppression), the performance of quantitative studies under various biological conditions and the profiling of protein expression during development and aging (for review, see Ref. [58]). In addition to revealing new diagnostic and therapeutic targets, high-throughput technologies could provide key insights related to comprehending mechanisms such as how the parasites invade host tissues and modulate their protective immune response [59,60].

In studies on parasitic nematodes, a widely adopted approach is to focus on the investigation of their secretomes. Apart from mediating interactions with the host (including modification of defense signaling pathways), excretory/secretory proteins may be an important source of potential immunogens to be used for diagnostics and vaccine development [61]. Several studies have thus far employed electrophoresis and/or liquid chromatography followed by MS/MS to identify secreted proteins from the helminths Haemonchus contortus [62], Trichinella spiralis and T. pseudospiralis [63,64], Teladorsagia circumcincta [65] and Brugia malayi [66-68]. Other proteomic studies on nematodes have focused on analyzing gender- and/or species-specific antigens [69-71], as well as the plasticity of protein expression patterns under different environmental conditions $[72,73]$.

The aim of the present study was to comparatively identify the most abundant proteins in crude extracts from female and male Angiostrongylus costaricensis, particularly their immunogenic proteins.

\section{Materials and methods}

\subsection{Parasites}

The life cycle of the parasites was maintained at the laboratory using Sigmodon hispidus rodents and the snail Biomphalaria glabrata as definitive and intermediate hosts, respectively. Three-month-old rats were orally infected with 30 L3 larvae/ animal. Adult worms were recovered by dissection of the mesenteric arteries of cotton rats after 40 days of infection [38]. They were extensively rinsed in PBS, segregated according to gender, weighted, and then stored at $-80^{\circ} \mathrm{C}$ until further use. Discrimination between genders was based on classical morphological criteria: females are usually longer and thinner than males and present an intestine full of blood, and males exhibit typical copulatory bursa with several rays and two copulatory spicules $[8,74,75]$. All procedures with animals were approved by the Animal Ethics Committee at Fiocruz (CEUA license \# P0246/05) and were carried out in accordance with the International Guiding Principles for Biomedical Research Involving Animals, as issued by the Council for the International Organizations of Medical Sciences.

\subsection{Optimization of protein extraction procedures}

Protein extraction was performed after maceration of the worms $(10 \mathrm{mg})$ in microcentrifuge tubes containing an abrasive resin (Sample Grinding Kit, GE Healthcare) and $150 \mu \mathrm{L}$ of one of the following extraction solutions: (A) $1 \%$ SDS, $60 \mathrm{mM}$ DTT and $40 \mathrm{mM}$ Tris base; (B) $8 \mathrm{M}$ urea, 4\% CHAPS, $60 \mathrm{mM}$ DTT, $40 \mathrm{mM}$ Tris base and 1\% v/v IPG buffer (same pH range of the IPG strip); (C) $7 \mathrm{M}$ urea, $2 \mathrm{M}$ thiourea, $4 \%$ CHAPS, $40 \mathrm{mM}$ Tris base, $60 \mathrm{mM}$ DTT and 1\% v/v IPG buffer (same $\mathrm{pH}$ range of the IPG strip). Extraction with solution $C$ was also performed in the presence of the Complete ${ }^{\mathrm{TM}}$ Protease Inhibitor Cocktail (Roche, Basel, Switzerland), following the manufacturer's instructions. After incubation for $1 \mathrm{~h}$ at room temperature with gentle shaking, cellular debris and resin were spun out $(16,000 \times g, 15 \mathrm{~min})$, and proteins were precipitated from the supernatant overnight with cold ethanol/ acetone [1(protein extract):4 (ethanol):4 (acetone) v/v] at $-20^{\circ} \mathrm{C}$. The precipitated proteins were sedimented at $16,000 \times \mathrm{g}$ for $30 \mathrm{~min}$, washed 3 times with ethanol/acetone/ water $(4: 4: 2 \mathrm{v} / \mathrm{v})$ and solubilized overnight at $4{ }^{\circ} \mathrm{C}$ in extraction solution $\mathrm{C}$ without Tris base. Aliquots collected at each extraction step were assayed for total protein content using the 2-D Quant Kit (GE Healthcare).

\subsection{SDS-PAGE}

Protein extracts were initially analyzed by homogeneous SDSPAGE (12\%) in the Mini-Protean II system (Bio-Rad Laboratories) under reducing conditions using $4 \%$ stacking gels [76]. Additionally, low molecular weight markers from GE Healthcare were used and gels were stained with $0.2 \%$ CBB R-250.

\subsection{2-DE}

Total cellular extracts of female and male adult worms were fractionated first on Immobiline DryStrips (IPG $11 \mathrm{~cm}$ pH 3-11 NL or $11 / 18 \mathrm{~cm} \mathrm{pH} \mathrm{4-7)(GE} \mathrm{Healthcare)} \mathrm{and} \mathrm{then} \mathrm{by} \mathrm{homoge-}$ neous 15\% SDS-PAGE as previously described [77]. Following in-gel sample rehydration at $30 \mathrm{~V}$ for $12 \mathrm{~h}$, the following IEF electric conditions for $18 \mathrm{~cm}$ IPG strips were used: $200 \mathrm{~V} / 1 \mathrm{~h}$, $500 \mathrm{~V} / 1 \mathrm{~h}, 1000 \mathrm{~V} / 1 \mathrm{~h}, 1000-8000 \mathrm{~V} / 30 \mathrm{~min}$, and $8000 \mathrm{~V} / 7 \mathrm{~h}$ $(60,000 \mathrm{VhT})$. For $11 \mathrm{~cm}$ IPG strips, the maximum voltage was limited to $6000 \mathrm{~V} / 6 \mathrm{~h}$ (44,000 VhT). Gels were stained with colloidal CBB G-250 or Sypro Ruby (Invitrogen) for total protein 
visualization or incubated with the glycan-specific stain ProQEmerald (Invitrogen) for the detection of glycoproteins, as specified by the manufacturer's instructions. CBB-stained gels were scanned using an Image Scanner (GE Healthcare), and image analysis was performed using Image Master 2D Platinum 7.0 software (GE Healthcare). Spot detection was automatically performed with minimal manual editing. For each gender, three independent sample preparations were analyzed by 2-DE. Protein spot abundances were expressed as a mean \pm standard deviation. Comparisons of spot abundances between female and male groups were performed using Student's t-test $(p \leq 0.01)$. Fluorescent images were acquired on a Typhoon Trio scanner (GE Healthcare) with a resolution of $100 \mu \mathrm{m}$ and photomultiplier (PTM) values adjusted to optimize sensitivity and avoid oversaturation. The excitation/emission wavelengths for Sypro Ruby and ProQ-Emerald were 488/610 and 532/520, respectively.

\subsection{Characterization of immunogenic proteins}

Immediately after electrophoresis, the proteins on 2-DE gels were transferred to PVDF membranes (Immun-Blot ${ }^{\mathrm{TM}} 0.2 \mu \mathrm{m}$, BioRad) at $270 \mathrm{~mA}$ for $3 \mathrm{~h}$ using the TE77 PWR semi-dry blotter (Amersham Biosciences). Two 2-DE gels were transferred at the same time by stacking them vertically in a multi-layered stack. After blocking unoccupied membrane sites overnight with TBS containing $0.05 \%$ Tween 20 and 5\% skim milk, the PVDF membrane was incubated for $2 \mathrm{~h}$ with pooled serum taken from Swiss Webster mice 28 days after experimental infection with A. costaricensis (1/1000 v/v dilution in freshly prepared blocking solution). After washing $3 \times$ for $10 \mathrm{~min}$ with TBS containing $0.05 \%$ Tween 20 , the membranes were further incubated for $2 \mathrm{~h}$ with the secondary antibody HRP-conjugated sheep anti-mouse IgG (whole antibody, GE Healthcare)(1/25,000 dilution in TBS $+0.05 \%$ Tween 20). The membranes were washed again with TBS+ Tween 20 and then incubated between two cellophane sheets with the SuperSignal West Dura Chemiluminescent Substrate (Thermo Scientific) prepared according to the manufacturer's instructions. Each membrane/cellophane "sandwich" was exposed to Hyperfilm ECL Film (GE Healthcare) for $3 \mathrm{~min}$. The spots on 2-DE blots were matched to their homologues in 2-DE gels using Image Master 2D Platinum 7.0 software (GE Healthcare).

\subsection{Protein analysis by mass spectrometry}

In-gel protein digestion, $\mathrm{N}$-terminal chemical derivatization of tryptic peptides with 4-sulphophenyl isothiocyanate (SPITC), and sample desalting with C18 ZipTip micropipette tips (Millipore) were performed as previously described [78]. All MS spectra were acquired in positive ion reflector mode on an AB Sciex MALDI-TOF/TOF 5800 Mass Spectrometer using Explorer software, version 4.0.0. An aliquot $(0.3 \mu \mathrm{L})$ of the desalted tryptic digest was deposited onto the target plate immediately before the addition of an equal volume of a saturated matrix solution [ $10 \mathrm{mg} / \mathrm{mL} \alpha$-cyano-4-hydroxycinnamic acid (Aldrich, Milwaukee, WI) in 50\% acetonitrile/0.1\% trifluoroacetic acid]. After sample drying at room temperature, both MS and MALDI-PSD data were acquired with a $1 \mathrm{kHz}$ laser. Typically, 2040 and 2000 shots were accumulated for spectra in MS mode and PSD mode, respectively. Up to 20 of the most intense ion signals with a signal-to-noise ratio above 30 were selected as precursors for MALDI-PSD acquisition, excluding common trypsin autolysis peaks and matrix ion signals. External calibration in MS mode was performed using a mixture of five peptides: des-Arg1-Bradykinin (m/z) 904.4680; angiotensin I $(\mathrm{m} / \mathrm{z})$ 1296.6850; Glu1-fibrinopeptide B $(\mathrm{m} / \mathrm{z})$ 1570.6770; ACTH (1-17) (m/z) 2093.0870 and ACTH (18-39) $(\mathrm{m} / \mathrm{z})$ 2465.1990. MALDI-PSD spectra were externally calibrated using known fragment ion masses observed in the spectrum of angiotensin I.

\subsection{Database searching and gene ontology analysis}

Following data acquisition, peak lists from uninterpreted spectra were created using the Peaks-to-Mascot script of 5800 Explorer software (Applied Biosystems) and uploaded to the online Mascot search engine (Matrix Science). The search considered carbamidomethylation as a static modification and methionine oxidation, propionamide cysteine and $\mathrm{N}$ terminal derivatization with SPITC as variable modifications. Up to two missed cleavages were accepted. The spectra were searched against NCBInr. Peaks Studio 5.2 [79] was used as an extra measure to confirm the interpretation of tandem spectra identified as described above; the same modification settings and protein database were used. We used PatternLab's Gene Ontology Explorer (GOEx) module $[80,81]$ to further interpret our list of identified proteins. First, we used Goanna [82] to

Table 1 - Quantitative analysis of extraction yields and protein recovery after different sample preparation methods. Protein concentration was measured using the 2D-Quant-kit assay.

\begin{tabular}{|c|c|c|c|c|c|c|c|}
\hline & \multirow[t]{2}{*}{ Extraction solutions } & \multicolumn{3}{|c|}{$\begin{array}{c}\text { Extraction yield } \\
\text { ( } \mu \mathrm{g} \text { ptn/mg worm) }\end{array}$} & \multicolumn{3}{|c|}{$\begin{array}{l}\text { \% Recovery after EtOH } \\
\text { precipitation }\end{array}$} \\
\hline & & Mean & SD & $\mathrm{n}$ & Mean & $\mathrm{SD}$ & $\mathrm{n}$ \\
\hline \multirow[t]{4}{*}{ Female } & A & 105.74 & 2.77 & 4 & ND & & \\
\hline & B & 86.11 & 9.06 & 4 & 60.78 & 6.86 & 4 \\
\hline & C & 84.10 & 11.71 & 11 & 91.52 & 8.83 & 10 \\
\hline & $\mathrm{C}+$ inhibitor cocktail & 81.34 & 8.58 & 2 & ND & & \\
\hline Male & $\mathrm{C}$ & 87.12 & 11.24 & 7 & 95.67 & 4.02 & 6 \\
\hline
\end{tabular}


assign GO terms to each identified protein by Blasting [83] them against the online SwissProt, TrEMBLE, and UniProt databases. This generated a text file containing each protein's accessions number and the corresponding GO terms. This file, together with the Gene Ontology database [84] (OBO v 1.2 downloaded from geneontology.org in March 1st 2011), served as an input to GOEx so that statistically over-represented GO terms $(p \leq 0.01)$ could be determined according to the hypergeometric distribution.

\section{Results and discussion \\ 3.1. Optimization of protein extraction}

Female specimens of A. costaricensis are longer than male worms $[8,74]$ and were recovered in higher numbers in infected Sigmodon hispidus. Therefore, the optimization of protein extraction conditions was performed only in females. Table 1 shows the quantitative results from grinding these parasites under different extraction conditions. Assuming SDS-based solution A as the gold standard (100\% extraction efficiency), we showed that both solutions B (containing urea as caothropic agent) and $C$ (containing urea/thiourea) were efficient in extracting approximately $80 \%$ of whole worm proteins. Qualitatively, SDS-PAGE profiles from all extraction conditions showed comparable patterns of protein bands with different staining intensities over the entire range of molecular masses from $14.4 \mathrm{kDa}$ to more than $97 \mathrm{kDa}$ (Fig. 3). After the addition of a protease inhibitor cocktail to solution $C$, no changes were observed in the extraction yield or the SDS-PAGE profile, indicating that proteolysis is not a major concern under the

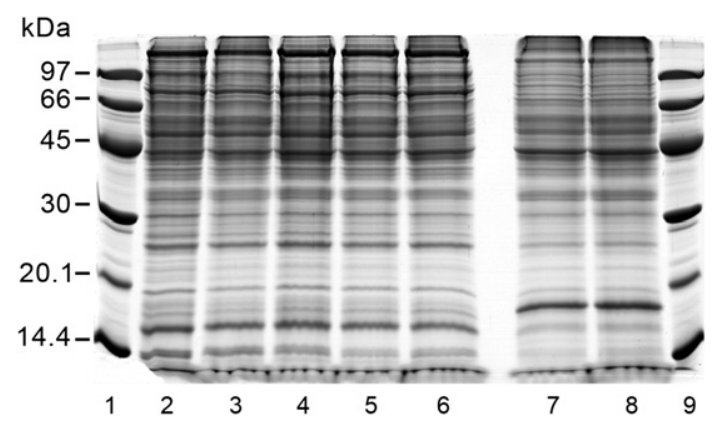

Fig. 3 - SDS-PAGE of protein extracts from adult Angiostrongylus costaricensis nematodes. Whole worms were ground in different solutions to optimize extraction conditions. The composition of solutions A-C is described in the Materials and methods section. Lanes 1 and 9, molecular mass markers; lane 2, female proteins extracted with solution A; lane 3 , female proteins extracted with solution $B$; lane 4, female proteins extracted with solution C; lane 5, female proteins extracted with solution C + Complete ${ }^{\mathrm{TM}}$ protease inhibitor cocktail; lane 6, female proteins extracted with solution $C$ and precipitated with ethanol/acetone; lane 7, male proteins extracted with solution $\mathrm{C}$; lane 8 , male proteins extracted with solution $\mathrm{C}$ and precipitated with ethanol/ acetone. Gels (12\%) were run under reducing conditions and stained with CBB R-250. The same amounts of protein $(20 \mu \mathrm{g} / 10 \mu \mathrm{L})$ were applied in lanes 2-8. denaturing conditions used here. Because protease inhibitors can additionally modify proteins and cause charge artifacts, they were not used in this study. Proteins were precipitated with a mixture of cold ethanol/acetone so that contaminants that might impair subsequent 2-DE analysis, such as salts and nucleic acids, could be removed [85]. No qualitative differences were observed in the unidimensional protein profiles of samples extracted with solution $\mathrm{C}$ before and after precipitation (Fig. 3). Regarding the recovery of proteins from ethanol/acetone

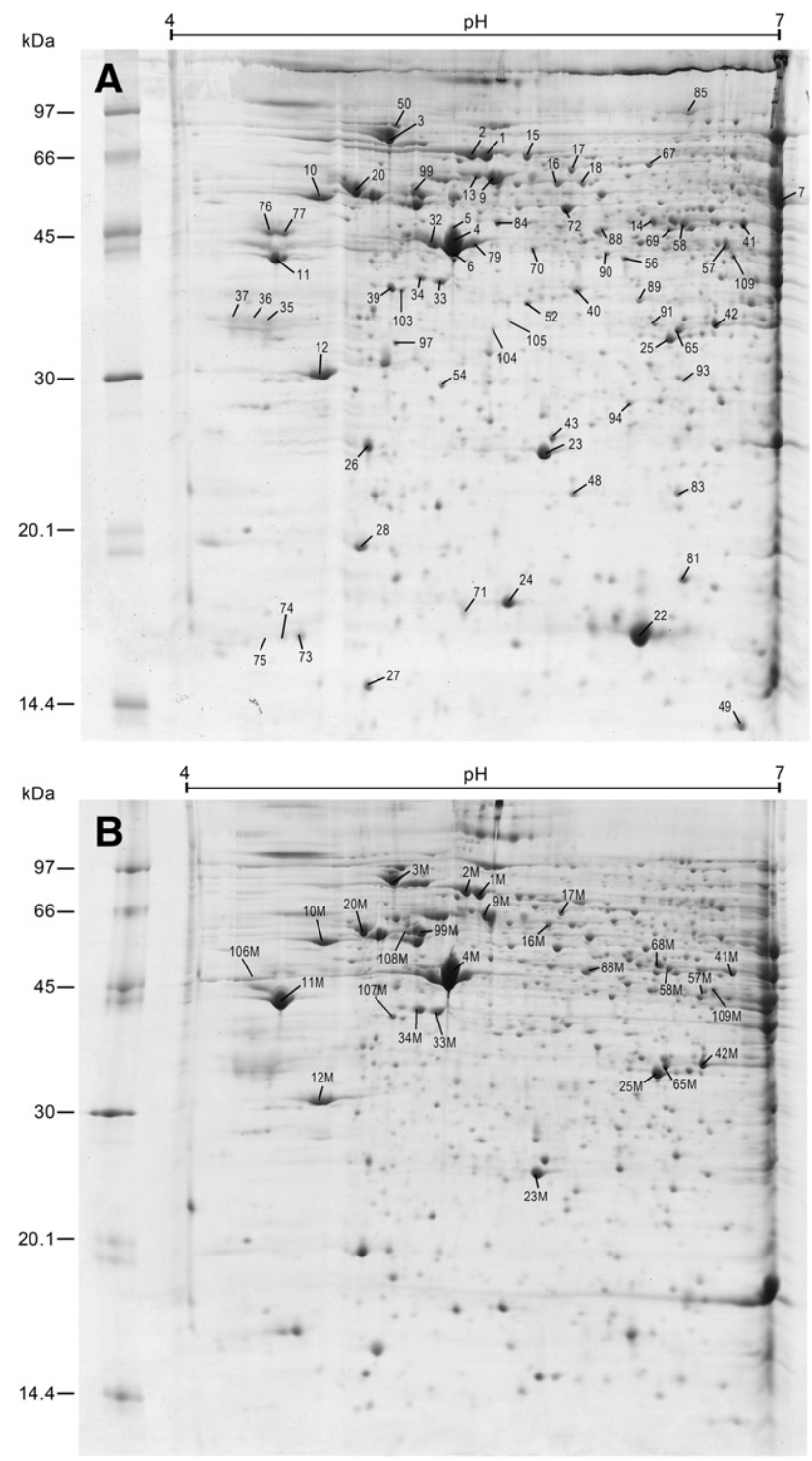

Fig. 4 - 2-DE gels of total protein extracts from adult Angiostrongylus costaricensis nematodes. Proteins $(0.5 \mathrm{mg})$ from female (A) and male (B) worms extracted with solution C were separated by 2-DE on $18 \mathrm{~cm}$ IPG strips pH 4-7, followed by $15 \%$ SDS-PAGE. Gels were run under reducing conditions and stained with colloidal CBB G-250. The migration of molecular mass markers is shown on the acidic side of the gel. Numbers refer to the spot identity used in the tables. The letter $\mathbf{M}$ placed after the spot number indicates male proteins. Numbers without a letter refer to female proteins. Representative images of three independent replicates are shown. 
pellets, the use of thiourea in combination with high concentrations of urea [86] dramatically increased the solubilization power of solution C as compared to solution B (Table 1). Under optimized conditions, male samples ground in solution $\mathrm{C}$ showed approximately the same extraction yield and percentage of protein recovery as females (Table 1). SDS-PAGE profiles were similar for both genders, although differences in the intensity distribution of the protein bands were evident (Fig. 3).

\subsection{Two-dimensional analysis of protein extracts}

To improve electrophoretic separation, extracts of female or male adult worms were independently fractionated by 2-DE. Using $11 \mathrm{~cm}$ IPG strips, pH 3-11 NL, approximately 800 protein spots were visualized by colloidal CBB staining (Fig. 1, Supplementary data). Although the body morphology and size are significantly different in female and male worms [87], their 2-DE profiles were similar, with less than $30 \%$ of unmatched spots being observed (which were concentrated in the more basic regions of the gels). Most protein spots $(\approx 60 \%)$ from both genders were focused between $\mathrm{pH} 5$ and 7 , with molecular masses ranging from 20.1 to $66 \mathrm{kDa}$. In such broad-range IPG strips, more than one protein may be focused within the same gel spot [88]. Therefore, we decided to further improve the proteome analysis by using $18 \mathrm{~cm}$ medium-range IPG strips, pH 4-7 (Fig. 4). Approximately 1000 protein spots were detected between $\mathrm{pH} 4-7$ on each individual gel. No significant gender-specific differences in expression levels were observed for $75 \%$ of these spots. Of the remaining $25 \%$ of protein spots, $7.5 \%$ and $10.4 \%$ were uniquely detected in female or male worms, respectively. These could represent true gender-specific proteins or quantitative differences between males and females (with the least abundant spots falling under the sensitivity threshold of the detection method used). Whether such differences represent biologically important variations remains to be determined.

\subsection{Protein identification by MALDI-PSD MS}

In an attempt to better characterize the protein profiles of A. costaricensis parasites, the most abundant spots shown in Fig. 4 were excised and analyzed by MALDI-PSD (Table 2 and Supplementary Table 1). It is important to note that only 12 gene sequences can be retrieved from the NCBInr database for A. costaricensis nematodes, all of which code for mitochondrial proteins. Hence, most of the uninterpreted experimental tandem spectra were matched to predicted fragment patterns from homologous species. To simplify the interpretation of the MALDI-PSD spectra, tryptic peptides were chemically derivatized with SPITC before MS analysis. This simple N-terminal sulfonation reaction leads to the formation of a much cleaner spectrum (almost exclusively) comprised of y-series ions, as b-series products are neutralized by a strongly negative modifying group $[78,89]$. Because the derivatization reaction is not $100 \%$ efficient, both derivatized and non-derivatized peptides were observed in most cases. Of the 106 dominant protein spots excised from 2-DE gels from females, 72 (68\%) were identified by mass spectrometry. For male samples, 27 out of the 46 processed spots (59\%) were positively identified. Although 16 spots gave rise to good quality MALDI-PSD spectra, they could not be identified; these peptide ions probably correspond to genes that have yet to be described.

\subsection{Interpretation of the identification results}

The GOEx tool [81] was used to search for associations between our MS data and Gene Ontology (GO) terms [84]. Several GO terms were statistically over-represented in our dataset, from which we highlight the following biological process terms: a) related to "macromolecule metabolic process" (GO:0009059-macromolecule biosynthetic process, GO:0019538-protein metabolic process, GO:0006508-proteolysis); b) related to "developmental process" (GO:0002164-larval development, GO:0048513-organ development, GO:0055115-entry into diapose); c) related to "response to stress" (GO:0006979-response to oxidative stress, GO:0006986-response to unfolded protein) and d) related to "biological regulation" (GO:0040008-regulation of growth, GO:0048518-positive regulation of biological process). The corresponding proteins for each enriched GO term are listed in Supplementary Table 2.

Not surprisingly, several of the most abundant proteins identified in A. costaricensis extracts were cytoskeleton-associated proteins, such as actin, myosin light chain, alpha tubulin, tropomyosin and collagen. These proteins play important roles in maintaining the body shape and muscle integrity of the nematodes $[71,90,91]$. The somatic musculature in nematodes is technically a part of the body wall, and it functions together with the pseudocoel and the cuticle as a hydrostatic skeleton [92] (Fig. 2G). Identified proteins involved in energy metabolism included, but were not limited to, cytochrome c oxydase, ATP synthase, enolase, glutamine synthetase, glutamate ammonia ligase, methionine adenosyltransferase and ABC transporter. Enolase is a multifaceted glycolytic protein that was traditionally thought to be restricted to the cytosol. Interestingly, some years ago, it was described on the surface of some helminths, where it binds to plasminogen and may be involved in the degradation of the host's extracellular matrix [93-96]. Proteins that directly interfere with host effector mechanism were also detected in the present proteomic study. Some of these are anti-oxidant proteins, such as peroxiredoxin, thioredoxin, translationally controlled tumor protein and aldehyde dehydrogenase. They effectively detoxify host-generated reactive oxygen species that could otherwise damage parasite cellular components, such as proteins, lipids and nucleic acids. Therefore, antioxidant proteins constitute a key factor favoring parasite survival inside the intravascular (mainly arterial) system, and thus contribute to the host-parasite relationship. These proteins are being investigated as putative protective antiparasite vaccines [97]. Other noteworthy identified proteins include As37 and cyclophilins, which are members of the immunoglobulin family. The latter is a folding helper enzyme belonging to the peptidyl-prolyl cis-trans isomerase class [98]. Both proteins have previously been described in other parasitic nematodes, such as Haemonchus contornus [62] and Brugia malayi [67], although their role in the parasites' immune evasion remains unknown. Finally, we identified a 14-3-3 protein, a $30 \mathrm{kDa}$ polypeptide belonging to a highly conserved family of molecules that regulate intracellular signal transduction and the cell cycle [99]. This protein has also been 
observed in other helminths, such as Echinococcus multilocularis, E. granulosus[100] and Schistosoma mansoni. In the last species, the 14-3-3 protein is believed to be involved in parasite growth and survival [101] and is being evaluated as a vaccine candidate against schistosomiasis [102].

The systematic profiling of A. costaricensis proteins described above contributes to our understanding of the parasite's physiology. For example, this comprehensive molecular characterization may eventually help to explain why traditional anthelmintic drugs seem to induce erratic migration of these parasites, instead of killing them, which may exacerbate the consequences of the infection [10]. Proteomics could additionally unveil important molecules involved in hostparasite crosstalk, leading to the development of more effective therapeutic interventions for controlling the disease. For example, immunoreactive proteins from A. costaricensis nematodes are largely unknown, contributing to the difficulty involved in specifically diagnosing abdominal angiostrongyliasis in humans. A number of severe cases are confirmed through histopathological examination of specimens obtained after surgical treatment. Such drastic intervention may be necessary for the correction of intestinal perforations or obstructions that are eventually observed in angiostrongyliasis infections [25,29]. The first immunochemical investigations have used antigen preparations made from crude adult worm $[22-24,103,104]$ or egg $[28,105]$ extracts from A. costaricensis. However, it is well known that crude antigenic preparations are not suitable for immunodiagnosis due to their broad cross-reactivity with other helminth species. Ideally, purified antigens specific to the parasite should be used in immunodiagnostic tests [23].

\subsection{Analysis of immunogenic proteins}

In the present study, we exploited proteomic tools to specifically identify immunogenic proteins in A. costaricensis. These proteins were recognized after blotting 2-DE gels loaded with male or female total protein extracts onto PVDF membranes probed with antisera from Swiss Webster mice experimentally infected with A. costaricensis (Fig. 5). Overall, the immunoblots for both sexes showed similar profiles of reactive proteins, although some inter-gender variations were detected. One of the most striking differences observed was a stronger response for a group of $30-40 \mathrm{kDa}$ female antigens focused between $\mathrm{pH}$ 4.5-5.5. Accordingly, when comparing adult worm antigens obtained under mild (non-denaturing) conditions in ELISA tests, Graeff-Teixeira et al. [103] reported that whole female extracts were twice as sensitive as male extracts in recognizing a proven acute human A. costaricensis infection. It was suggested that the strong antigenicity of eggs produced by female worms may contribute to explaining such differences [28]. In fact, each female presents a large number of eggs inside two uteri, which were obligatorily included in the proteomic analysis of the female pool (Fig. 2H).

Identifying immunoreactive spots on Western blots corresponding to CBB-stained proteins was not simple, mainly due to the poor correlation between immunogenicity and protein abundance, as described previously for other helminth parasites $[62,67]$. For example, actin spots were not recognized by antisera from infected mice although they represent the most abundant protein in the worm extracts. This was not unexpected because actin is a major constituent of eukaryotic cells and is widely observed throughout the animal kingdom, usually together with myosin $[106,107]$. It is unknown whether actin plays a critical role in A. costaricensis intestinal epithelial endocytosis [108]. On the other hand, strongly immunogenic proteins focused in the central region of the male blot corresponded to regions of the gel where several faintly CBB-stained spots (or no spots at all) could be detected (Fig. 2, Supplementary data). To further improve these results, we are presently carrying out assays for the direct detection of antigens in the polyacrylamide gels and/or immunoprecipitation (pull-down) followed by nLCMS/MS analysis.

The only immunoreactive protein spots detected by mice antisera that could be unequivocally identified by MALDI-PSD were heat shock proteins (HSPs)[spots \# 1(M), 2(M) and 3], a putative abnormal DAuer Formation family member [spot \# $3 \mathrm{M}$ ] and galectins [spots \# 25(M), 42(M) and 65(M)] (Fig. 5). HSPs and galectins, as well as several other non-immunogenic proteins of A. costaricensis, were found in multiple protein spots, indicating the presence of protein isoforms. Indeed, when staining the gels with ProQ-Emerald, a glycan-specific reagent, several protein spots were shown to be glycosylated (Fig. 3, Supplementary data), a common feature among helminth parasite antigens [109]. HSPs act as molecular chaperones, regulating protein folding in the cell. These proteins are related to the adaptive response of the parasite to the host immune system. Furthermore, in various infectious disease models, vaccination strategies using HSPs have induced significant protection [110]. Although HSPs also present a particularly high degree of structural conservation during evolution that must reflect the perpetuation of functions necessary for cell survival [111], their immunogenicity is highly dependent on the presence of functional phagocytic cells in the host [112]. Calreticulin and disulfide isomerase are other proteins related to protein folding that were identified in A. costaricensis extracts. In contrast to the HSPs, they were not immunogenic. Calreticulin is a well conserved $46 \mathrm{kDa}$ protein that plays important roles in the regulation of key cellular functions [113]. This protein has been identified as a potent virulence factor in Trypanosoma cruzi [114], as necessary for stress responses and fertility in C. elegans [115] and as involved in immune responses in Hekigmosomoides polygyrus [116] and in Necator americanus [117]. Protein disulfide isomerase is a multi-functional enzyme that, in addition to its enzymatic activity involved in protein folding, seems to be essential for viability and extracellular matrix formation in C. elegans nematodes [118].

In male blots, immunogenic spot \#3M was identified as a DAuer formation protein. In female blots, the corresponding less reactive spot matched an HSP. A BLASTp search in the NCBInr database indicated high sequence similarity (91\%) between a Dauer formation protein and Heat Shock Protein 90. Dauer formation (daf) genes have been described as controlling both larval development and adult longevity in C. elegans $[119,120]$. These genes can prolong larval development under adverse environmental conditions, such as a lack of food and/ or high temperature [121]. They also extend the adult lifespan during restricted nutrition periods and changes in temperature [122]. 
Table 2 - Summary list of the most abundant protein spots of A. costaricensis adult extracts identified by MALDI-PSD MS. The letter $\mathrm{M}$ placed after the spot number indicates male proteins. Numbers without a letter refer to female proteins. Protein analysis was performed by running the Mascot search engine against the NCBInr database. For a more detailed description of all identified proteins, see Supplementary Table 1.

Spot no. Protein name

\begin{tabular}{|c|c|}
\hline $1,1 \mathrm{M}, 2,2 \mathrm{M}, 3$ & Heat shock protein \\
\hline $3 \mathrm{M}$ & Putative abnormal DAuer formation family member \\
\hline $4,4 \mathrm{M}, 5,6$ & Actin \\
\hline 7 & Elongation factor 1 alpha \\
\hline $9,9 \mathrm{M}$ & Heat shock protein \\
\hline $10,10 \mathrm{M}$ & Calreticulin \\
\hline $11,11 \mathrm{M}$ & Tropomyosin \\
\hline $12,12 \mathrm{M}$ & Fourteen-three-three family member \\
\hline 13 & Heat shock protein \\
\hline 14 & Methionine adenosyltransferase \\
\hline 15 & COLlagen family member \\
\hline $16,16 \mathrm{M}$ & ССТ-2 \\
\hline $17,17 \mathrm{M}, 18$ & Chaperonin containing TCP-1 family member \\
\hline $20,20 \mathrm{M}$ & Protein disulfide isomerase \\
\hline $22,23,23 \mathrm{M}$ & Peroxiredoxin \\
\hline 24 & Hypothetical protein Rsph17025_3168 \\
\hline $25,25 \mathrm{M}$ & Galectin \\
\hline 26 & Translationally controlled tumor protein \\
\hline 27 & D-aminoacylase domain protein \\
\hline 28 & C. briggsae CBR-MLC-2.2 protein \\
\hline 32 & Actin \\
\hline $33,33 \mathrm{M}, 34,34 \mathrm{M}$ & As37 \\
\hline $35,36,37$ & Putative Lin-5 (five) interacting protein \\
\hline 39 & Ribosomal protein, small subunit family member \\
\hline 40 & Stress-induced-phosphoprotein 1 \\
\hline $41,41 \mathrm{M}$ & Enolase \\
\hline $42,42 \mathrm{M}$ & Galectin \\
\hline 43 & PREDICTED: similar to mitochondrial truncated thioredoxin-dependent peroxide reductase precursor \\
\hline 48 & Predicted protein \\
\hline 49 & ABC transporter related \\
\hline 50 & Hypothetical protein T05E11.3 \\
\hline 52 & NAD-dependent epimerase/dehydratase \\
\hline 54 & 20 s proteasome alpha5 subunit \\
\hline 56 & Hypothetical protein F17C11.9 \\
\hline $57,57 \mathrm{M}$ & Glutamate-ammonia ligase \\
\hline $58,58 \mathrm{M}$ & Enolase \\
\hline $65,65 \mathrm{M}$ & Galectin \\
\hline 67 & Chaperonin containing TCP-1 family member \\
\hline $68 \mathrm{M}$ & Ubiquinol-Cytochrome c oxidoReductase complex family member \\
\hline 69 & CRE-AHCY-1 protein \\
\hline 70 & Uracil-DNA glycosylase \\
\hline 71 & Cytochrome $C$ oxidase family member \\
\hline 72 & Hypothetical protein BURPS1710b_A0185 \\
\hline 73,74 & Alkali myosin light chain \\
\hline 75 & SUMO (ubiquitin-related) homolog family member (smo-1) \\
\hline 76,77 & Putative nucleosome binding protein \\
\hline 79 & Putative beta-actin \\
\hline 81 & Hypothetical protein ckrop_1216 \\
\hline 83 & CalPoNin family member \\
\hline 84 & PREDICTED: similar to aldehyde dehydrogenase $1 \mathrm{~A} 2$ isoform 2 \\
\hline 85 & Primosomal protein $\mathrm{N}^{\prime}$ \\
\hline $88 \mathrm{M}$ & Hypothetical protein \\
\hline 89 & Hypothetical protein Y24D9A.8 \\
\hline 90 & Activator of $90 \mathrm{kDa}$ heat shock protein ATPase homolog 1 \\
\hline 91 & Galectin-1 \\
\hline 93 & C. briggsae CBR-PAS- 6 protein \\
\hline 94 & Heat shock protein \\
\hline 97 & Predicted protein \\
\hline 99, $99 \mathrm{M}$ & Alpha tubulin \\
\hline 103 & Protein farnesyltransferase/geranylgeranyltransferase putative \\
\hline 104 & Hypothetical protein \\
\hline 105 & Hypothetical protein Y46G5A.19 \\
\hline
\end{tabular}




\section{Table 2 (continued)}

Spot no.

\section{$106 \mathrm{M}$}

$107 \mathrm{M}$

$108 \mathrm{M}$

$109,109 \mathrm{M}$
Protein name

Putative nucleosome binding protein

Putative histone-binding protein Caf1

Alpha tubulin

Glutamate-ammonia ligase
Galectins were also recognized by mice antisera as immunogenic proteins in A. costaricensis. They were identified in several spots and are members of the galactoside-binding lectin family, being characterized by a typical motif of conserved amino acids in their carbohydrate recognition domain(s) [123]. The biological function of nematode galectins is not well understood, although they may be important for survival and interaction with the host [124]. Additionally, they seem to be involved in mediating immune recognition and modulation of the host response via an unknown mechanism, which may involve downregulation of the host's innate immunity [125]. Based on their primary structure and subunit architecture, galectins have been classified as proto (subunit molecular mass $14.5-16 \mathrm{kDa})$, chimera $(29-35 \mathrm{kDa})$ and tandem repeat (32-36 kDa) types [126] or galectins 1-12 [127]. These proteins have been described in several organisms and in C. elegans galectin-1 appears to be associated with the cuticle and pharynx of the adult worm [128].

\section{Conclusions}

To our knowledge, this work represents the first systematic effort to characterize the proteome of male and female A. costaricensis worms. Several important features of these proteomes were uncovered, such as the identity of the dominant proteins in adult nematode extracts and the overall characteristics of antigens detected by antisera from infected rats. These results will certainly contribute to improving our understanding of the host-parasite relationship, as well as assisting searches for candidate proteins for diagnostic assays and the treatment of abdominal angiostrongyliasis.

Supplementary materials related to this article can be found online at doi:10.1016/j.jprot.2011.04.031.

\section{Acknowledgements}

This research was supported by Brazilian grants from Fiocruz (PAPES V and PDTIS), Conselho Nacional de Desenvolvimento Científico e Tecnológico (CNPq), Fundação de Amparo à Pesquisa do Estado do Rio de Janeiro (FAPERJ) and Coordenação de Aperfeiçoamento de Pessoal de Nível Superior (CAPES). We thank the staff of the Toxinology and Pathology LaboratoriesIOC/Fiocruz for excellent technical assistance. We gratefully acknowledge Dr. André Teixeira S. Ferreira and Dr. Richard H. Valente (Toxinology Laboratory-IOC/Fiocruz) for their assistance with the mass spectrometric analysis. We also thank Monique R. O. Trugilho (Toxinology Laboratory-IOC/Fiocruz) for helping with 2-DE gel image analysis. We are grateful to Heloisa M. N. Diniz and Cristina S. Ferreira (Image Production and Treatment Service - IOC/Fiocruz) for processing the figures and creating the life cycle cartoon. KMR thanks CAPES for her PhD fellowship. PCC thanks CAPES/Fiocruz 30-2006 for his fellowship.

\section{R E F E R E N C E S}

[1] Morera P, Céspedes R. Angiostrongylus costaricensis n. sp. (Nematoda: Metastrongyloidea), a new lungworm occurring in man in Costa Rica. Rev Biol Trop 1971;18:173-85.

[2] Eamsobhana P, Lim PE, Solano G, Zhang H, Gan X, Yong HS. Molecular differentiation of Angiostrongylus taxa (Nematoda: Angiostrongylidae) by cytochrome c oxidase subunit I (COI) gene sequences. Acta Trop 2010;116:152-6.

[3] Wang QP, Lai DH, Zhu XQ Chen XG, Lun ZR. Human angiostrongyliasis. Lancet Infect Dis 2008;8:621-30.

[4] Kliks MM, Palumbo NE. Eosinophilic meningitis beyond the Pacific Basin: the global dispersal of a peridomestic zoonosis caused by Angiostrongylus cantonensis, the nematode lungworm of rats. Soc Sci Med 1992;34:199-212.

[5] Pien FD, Pien BC. Angiostrongylus cantonensis eosinophilic meningitis. Int J Infect Dis 1999;3:161-3.

[6] Caldeira RL, Mendonça CL, Goveia CO, Lenzi HL, Graeff-Teixeira C, Lima WS, et al. First record of molluscs naturally infected with Angiostrongylus cantonensis (Chen, 1935) (Nematoda: Metastrongylidae) in Brazil. Mem Inst Oswaldo Cruz 2007;102:887-9.

[7] Maldonado Jr A, Simões RO, Oliveira AP, Motta EM, Fernandez MA, Pereira ZM, et al. First report of Angiostrongylus cantonensis (Nematoda: Metastrongylidae) in Achatina fulica (Mollusca: Gastropoda) from Southeast and South Brazil. Mem Inst Oswaldo Cruz 2010;105:938-41.

[8] Morera P. Life history and redescription of Angiostrongylus costaricensis Morera and Céspedes, 1971. Am J Trop Med Hyg 1973;22:613-21.

[9] Céspedes R, S. J., Mekbel S, Troper L, Müllner F, Morera P. Granulomas entéricos y linfáticos con intensa eosinofilia tissular producidos por un estrongilideo (Strongylata). Acta Med Costarric 1967;10:325-55.

[10] Morera P, Bontempo I. Acción de algunos antihelminticos sobre Angiostrongylus costaricensis. Rev Méd Hosp Nac Niños Costa Rica 1985;20:165-74.

[11] Ubelaker JE, Hall NM. First report of Angiostrongylus costaricensis Morera and Céspedes 1971 in the United States. J Parasitol 1979;65:307.

[12] Hulbert TV, Larsen RA, Chandrasoma PT. Abdominal angiostrongyliasis mimicking acute appendicitis and Meckel's diverticulum: report of a case in the United States and review. Clin Infect Dis 1992;14:836-40.

[13] Ash LR. Human anisakiasis misdiagnosed as abdominal angiostrongyliasis. Clin Infect Dis 1993;16:332-4. 


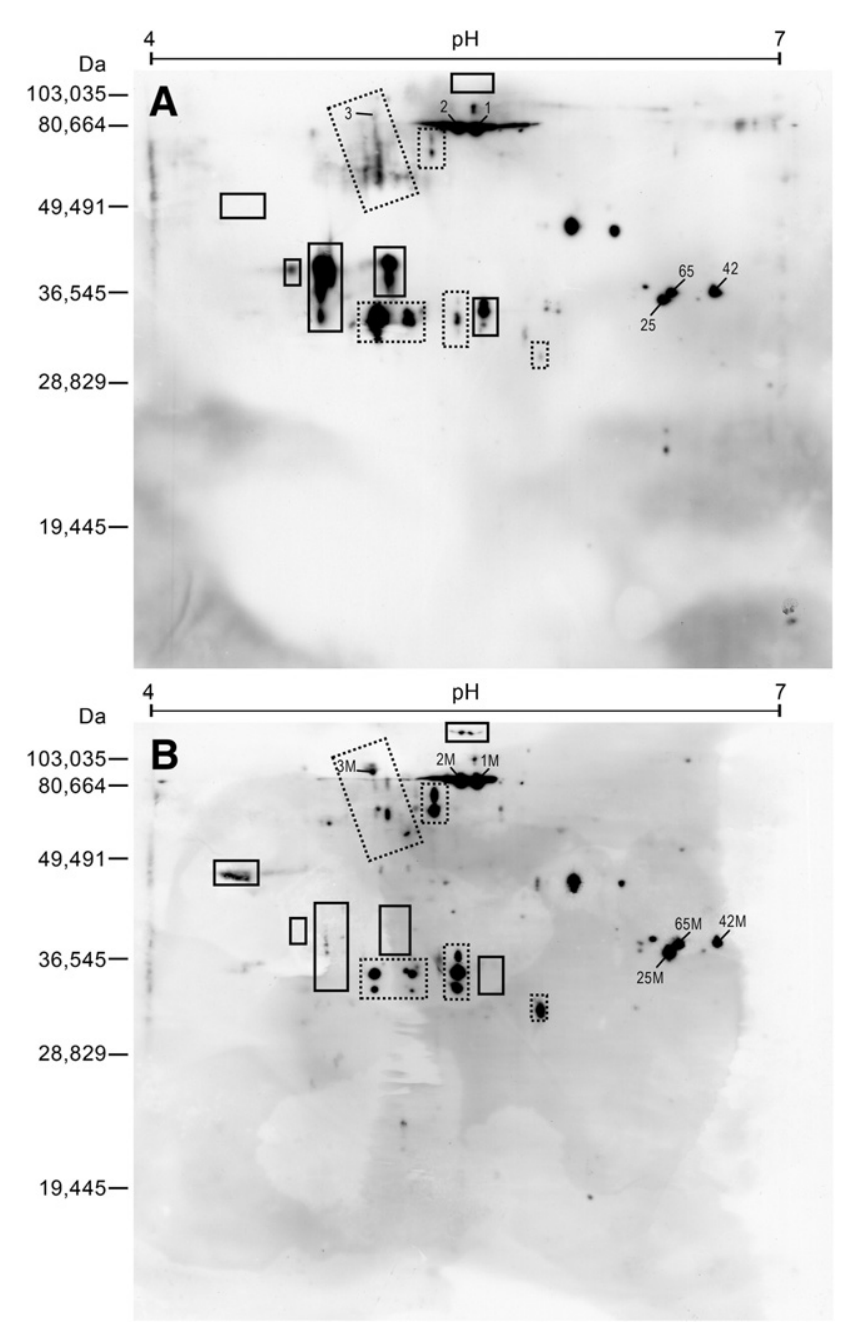

Fig. 5 - 2-DE/immunoblot of protein extracts from adult Angiostrongylus costaricensis nematodes. Proteins $(0.1 \mathrm{mg})$ from female (A) and male (B) worms extracted with solution C were fractionated on $18 \mathrm{~cm}$ IPG strips $\mathrm{pH} 4-7$, followed by $15 \%$ SDS-PAGE (reducing conditions), and further electroblotted onto a PVDF membrane that was probed with antisera from mice infected with $A$. costaricensis. After incubation with an anti-mouse secondary antibody conjugated to HRP, the membrane was developed by the addition of an ECL substrate. The migration of pre-stained molecular mass markers is indicated on the acidic side of the gel. Dotted-line boxes enclose protein spots with different signal intensities on female and male blots. Regions containing reactive spots exclusively found in one gender are indicated by solid-line boxes. Numbers refer to the spot identity used in the tables. The letter $\mathrm{M}$ placed after the spot number indicates male proteins. Numbers without a letter refer to female proteins.

[14] Kramer MH, Greer GJ, Quiñonez JF, Padilla NR, Hernández B, Arana BA, et al. First reported outbreak of abdominal angiostrongyliasis. Clin Infect Dis 1998;26:365-72.

[15] Morera P, Ash LR. Studies on the intermediate host of Angiostrongylus costaricensis (Morera and Céspedes, 1971). Bol Chil Parasitol 1970;25:135.

[16] Rodriguez R, Agostini AA, Porto SM, Olivaes AJ, Branco SL, Genro JP, et al. Dogs may be a reservoir host for
Angiostrongylus costaricensis. Rev Inst Med Trop Sao Paulo 2002;44:55-6.

[17] Mendonça CL, Carvalho OS, Mota EM, Lenzi HL. Development of Angiostrongylus costaricensis Morera and Cespedes 1971 (Nematoda: Angiostrongylidae) larvae in the intermediate host Sarasinula marginata (Semper 1885) (Mollusca: Soleolifera). Parasitol Res 2008;102:861-5.

[18] Carvalho Odos S, Teles HM, Mota EM, Lafeta C, de Mendonça GF, Lenzi HL. Potentiality of Achatina fulica Bowdich, 1822 (Mollusca: Gastropoda) as intermediate host of the Angiostrongylus costaricensis Morera \& Céspedes 1971. Rev Soc Bras Med Trop 2003;36:743-5.

[19] Graeff-Teixeira C. Expansion of Achatina fulica in Brazil and potential increased risk for angiostrongyliasis. Trans R Soc Trop Med Hyg 2007;101:743-4.

[20] Thiengo SC, Maldonado A, Mota EM, Torres EJ, Caldeira R, Carvalho OS, et al. The giant African snail Achatina fulica as natural intermediate host of Angiostrongylus cantonensis in Pernambuco, northeast Brazil. Acta Trop 2010;115:194-9.

[21] Rambo PR, Agostini AA, Graeff-Teixeira C. Abdominal angiostrongyliasis in southern Brazil-prevalence and parasitic burden in mollusc intermediate hosts from eighteen endemic foci. Mem Inst Oswaldo Cruz 1997;92:9-14.

[22] Graeff-Teixeira C, Goulart AH, de Brum CO, Laitano AC, Sievers-Tostes C, Zanini GM, et al. Longitudinal clinical and serological survey of abdominal angiostrongyliasis in Guapore, southern Brazil, from 1995 to 1999. Rev Soc Bras Med Trop 2005;38:310-5.

[23] Geiger SM, Laitano AC, Sievers-Tostes C, Agostini AA, Schulz-Key H, Graeff-Teixeira C. Detection of the acute phase of abdominal angiostrongyliasis with a parasite-specific IgG enzyme linked immunosorbent assay. Mem Inst Oswaldo Cruz 2001;96:515-8.

[24] Palominos PE, Gasnier R, Rodriguez R, Agostini AA, Graeff-Teixeira C. Individual serological follow-up of patients with suspected or confirmed abdominal angiostrongyliasis. Mem Inst Oswaldo Cruz 2008;103:93-7.

[25] Graeff-Teixeira C, Camillo-Coura L, Lenzi HL. Abdominal angiostrongyliasis-an under-diagnosed disease. Mem Inst Oswaldo Cruz 1987;82(Suppl 4):353-4.

[26] Morera P. Angiostrongiliasis abdominal, Un problema de salud pública? Rev Asoc Guatem Parasitol Med Trop 1987;2: 9-11.

[27] Morera P, Amador JA. Prevalencia de la angiostrongilosis abdominal y la distribución estacional de la precipitación. Rev Costarric Salud Pública 1998;7:1-14.

[28] Mesen-Ramirez P, Abrahams-Sandi E, Fernandez-Quesada $\mathrm{K}$, Morera P. Angiostrongylus costaricensis egg antigen for the immunodiagnosis of abdominal angiostrongyliasis. J Helminthol 2008;82:251-4.

[29] Graeff-Teixeira C, Camillo-Coura L, Lenzi HL. Histopathological criteria for the diagnosis of abdominal angiostrongyliasis. Parasitol Res 1991;77:606-11.

[30] Chabaud AG. Description of Stefanskostrongylus dubosti n. sp., parasite of Potamogale and attempt at classification of Angiostrongylidae nematodes. Ann Parasitol Hum Comp 1972;47:735-44.

[31] Ubelaker JE. Systematics of species referred to the genus Angiostrongylus. J Parasitol 1986;72:237-44.

[32] Baylis HS. On a collection of nematodes from Nigerian mammals (chiefly rodents). Parasitology 1928;20:280-304.

[33] Fontanilla IK, Wade CM. The small subunit (SSU) ribosomal (r) RNA gene as a genetic marker for identifying infective 3rd juvenile stage Angiostrongylus cantonensis. Acta Trop 2008;105:181-6.

[34] Caldeira RL, Carvalho OS, Mendonça CL, Graeff-Teixeira C, Silva MC, Ben R, et al. Molecular differentiation of Angiostrongylus costaricensis, A. cantonensis, and A. vasorum 
by polymerase chain reaction-restriction fragment length polymorphism. Mem Inst Oswaldo Cruz 2003;98: 1039-43.

[35] Jefferies R, Shaw SE, Viney ME, Morgan ER. Angiostrongylus vasorum from South America and Europe represent distinct lineages. Parasitology 2009;136:107-15.

[36] Eamsobhana P, Lim PE, Zhang H, Gan X, Yong HS. Molecular differentiation and phylogenetic relationships of three Angiostrongylus species and Angiostrongylus cantonensis geographical isolates based on a $66-\mathrm{kDa}$ protein gene of $\mathrm{A}$. cantonensis (Nematoda: Angiostrongylidae). Exp Parasitol 2010;126:564-9.

[37] Mota EM, Lenzi HL. Angiostrongylus costaricensis life cycle: a new proposal. Mem Inst Oswaldo Cruz 1995;90:707-9.

[38] Mota EM, Lenzi HL. Angiostrongylus costaricensis: complete redescription of the migratory pathways based on experimental Sigmodon hispidus infection. Mem Inst Oswaldo Cruz 2005;100:407-20.

[39] Vázquez JJ, Boils PL, Sola JJ, Carbonell F, de Juan Burgueño M, Giner V, et al. Angiostrongyliasis in a European patient: a rare cause of gangrenous ischemic enterocolitis. Gastroenterology 1993;105:1544-9.

[40] Neafie RC, Marty AM. Unusual infections in humans. Clin Microbiol Rev 1993;6:34-56.

[41] Silvera CT, Ghali VS, Roven S, Heimann J, Gelb A. Angiostrongyliasis: a rare cause of gastrointestinal hemorrhage. Am J Gastroenterol 1989;84:329-32.

[42] Loria-Cortes R, Lobo-Sanahuja JF. Clinical abdominal angiostrongylosis. A study of 116 children with intestinal eosinophilic granuloma caused by Angiostrongylus costaricensis. Am J Trop Med Hyg 1980;29:538-44.

[43] Lobo Sanahuja F, Loria Cortes R, Gonzalez G. Abdominal angiostrongylosis. Clinical aspects, treatment and review of the literature. Bol Med Hosp Infant Mex 1987;44:4-9.

[44] Graeff-Teixeira C, Camillo-Coura L, Lenzi HL. Clinical and epidemiological aspects of abdominal angiostrongyliasis in southern Brazil. Rev Inst Med Trop Sao Paulo 1991;33:373-8.

[45] Morera P, Perez F, Mora F, Castro L. Visceral larva migrans-like syndrome caused by Angiostrongylus costaricensis. Am J Trop Med Hyg 1982;31:67-70.

[46] Duarte Z, Morera P, Vuong PN. Abdominal angiostrongyliasis in Nicaragua: a clinico-pathological study on a series of 12 cases reports. Ann Parasitol Hum Comp 1991;66:259-62.

[47] Vázquez JJ, Sola JJ, Boils PL. Hepatic lesions induced by Angiostrongylus costaricensis. Histopathology 1994;25:489-91.

[48] Rodriguez R, Dequi RM, Peruzzo L, Mesquita PM, Garcia E, Fornari F. Abdominal angiostrongyliasis: report of two cases with different clinical presentations. Rev Inst Med Trop Sao Paulo 2008;50:339-41.

[49] Solano-Parada J, Gonzalez-Gonzalez G, Torro LM, dos Santos MF, Espino AM, Burgos M, et al. Effectiveness of intranasal vaccination against Angiostrongylus costaricensis using a serine/threonine phosphatase $2 \mathrm{~A}$ synthetic peptide and recombinant antigens. Vaccine 2010;28:5185-96.

[50] Harris TW, Antoshechkin I, Bieri T, Blasiar D, Chan J, Chen WJ, et al. WormBase: a comprehensive resource for nematode research. Nucleic Acids Res 2010;38:D463-7.

[51] The_C.elegans_Sequencing_Consortium. Genome sequence of the nematode C. elegans: a platform for investigating biology. Science 1998;282:2012-8.

[52] Stein LD, Bao Z, Blasiar D, Blumenthal T, Brent MR, Chen N, et al. The genome sequence of Caenorhabditis briggsae: a platform for comparative genomics. PLoS Biol 2003;1:E45.

[53] Ghedin E, Wang S, Spiro D, Caler E, Zhao Q Crabtree J, et al. Draft genome of the filarial nematode parasite Brugia malayi. Science 2007;317:1756-60.

[54] Abad P, Gouzy J, Aury JM, Castagnone-Sereno P, Danchin EG, Deleury E, et al. Genome sequence of the metazoan plant-parasitic nematode Meloidogyne incognita. Nat Biotechnol 2008;26:909-15.
[55] Opperman CH, Bird DM, Williamson VM, Rokhsar DS, Burke $\mathrm{M}$, Cohn J, et al. Sequence and genetic map of Meloidogyne hapla: A compact nematode genome for plant parasitism. Proc Natl Acad Sci U S A 2008;105:14802-7.

[56] Dieterich C, Clifton SW, Schuster LN, Chinwalla A, Delehaunty K, Dinkelacker I, et al. The Pristionchus pacificus genome provides a unique perspective on nematode lifestyle and parasitism. Nat Genet 2008;40:1193-8.

[57] Mitreva M, Jasmer DP, Zarlenga DS, Wang Z, Abubucker S, Martin J, et al. The draft genome of the parasitic nematode Trichinella spiralis. Nat Genet 2011;43:228-35.

[58] Shim YH, Paik YK. Caenorhabditis elegans proteomics comes of age. Proteomics 2010;10:846-57.

[59] Mitreva M, Zarlenga DS, McCarter JP, Jasmer DP. Parasitic nematodes - from genomes to control. Vet Parasitol 2007;148:31-42.

[60] Barrett J. Forty years of helminth biochemistry. Parasitology 2009:1-10.

[61] Ranganathan S, Garg G. Secretome: clues into pathogen infection and clinical applications. Genome Med 2009;1: 113.

[62] Yatsuda AP, Krijgsveld J, Cornelissen AW, Heck AJ, de Vries E. Comprehensive analysis of the secreted proteins of the parasite Haemonchus contortus reveals extensive sequence variation and differential immune recognition. J Biol Chem 2003;278:16941-51.

[63] Robinson M, Gare D, Connolly B. Profiling excretory/secretory proteins of muscle larvae by two-dimensional gel electrophoresis and mass spectrometry. Vet Parasitol 2005;132:37-41.

[64] Robinson MW, Greig R, Beattie KA, Lamont DJ, Connolly B. Comparative analysis of the excretory-secretory proteome of the muscle larva of Trichinella pseudospiralis and Trichinella spiralis. Int J Parasitol 2007;37:139-48.

[65] Craig H, Wastling JM, Knox DP. A preliminary proteomic survey of the in vitro excretory/secretory products of fourth-stage larval and adult Teladorsagia circumcincta. Parasitology 2006;132:535-43.

[66] Moreno Y, Geary TG. Stage- and gender-specific proteomic analysis of Brugia malayi excretory-secretory products. PLoS Negl Trop Dis 2008;2:e326.

[67] Hewitson JP, Harcus YM, Curwen RS, Dowle AA, Atmadja AK, Ashton PD, et al. The secretome of the filarial parasite, Brugia malayi: proteomic profile of adult excretory-secretory products. Mol Biochem Parasitol 2008;160:8-21.

[68] Bennuru S, Semnani R, Meng Z, Ribeiro JM, Veenstra TD, Nutman TB. Brugia malayi excreted/secreted proteins at the host/parasite interface: stage- and gender-specific proteomic profiling. PLoS Negl Trop Dis 2009;3:e410.

[69] Dea-Ayuela MA, Bolas-Fernandez F. Two-dimensional electrophoresis and mass spectrometry for the identification of species-specific Trichinella antigens. Vet Parasitol 2005;132:43-9.

[70] Calvo E, Flores-Romero P, Lopez JA, Navas A. Identification of proteins expressing differences among isolates of Meloidogyne spp. (Nematoda: Meloidogynidae) by nano-liquid chromatography coupled to ion-trap mass spectrometry. J Proteome Res 2005;4:1017-21.

[71] Yan F, Xu L, Liu L, Yan R, Song X, Li X. Immunoproteomic analysis of whole proteins from male and female adult Haemonchus contortus. Vet J 2010;185:174-9.

[72] Islam MK, Miyoshi T, Yokomizo Y, Tsuji N. The proteome expression patterns in adult Ascaris suum under exposure to aerobic/anaerobic environments analyzed by two-dimensional electrophoresis. Parasitol Res 2004;93:96-101.

[73] Morgan C, LaCourse EJ, Rushbrook BJ, Greetham D, Hamilton $\mathrm{JV}$, Barrett J, et al. Plasticity demonstrated in the proteome of a parasitic nematode within the intestine of different host strains. Proteomics 2006;6:4633-45. 
[74] Thiengo SC, Vicente JJ, Pinto RM. Redescription of Angiostrongylus (Paranstrongylus) costaricensis Morera \& Céspedes (nematoda: metastrongyloidea) from brazilian strain. Rev Bras Zool 1997;14:839-44.

[75] Ubelaker JE. Systematics of species referred to the genus Angiostrongylus. J Parasitol 1986;72:237-44.

[76] Laemmli UK. Cleavage of structural proteins during the assembly of the head of bacteriophage T4. Nature 1970;227: 680-5.

[77] Rocha SL, Neves-Ferreira AG, Trugilho MR, Chapeaurouge A, Leon IR, Valente RH, et al. Crotalid snake venom subproteomes unraveled by the antiophidic protein DM43. J Proteome Res 2009;8:2351-60.

[78] León IR, Neves-Ferreira AGC, Valente RH, Mota EM, Lenzi HL, Perales J. Improved protein identification efficiency by mass spectrometry using $\mathrm{N}$-terminal chemical derivatization of peptides from Angiostrongylus costaricensis, a nematode with unknown genome. J Mass Spectrom 2007;42:781-92.

[79] Ma B, Zhang K, Hendrie C, Liang C, Li M, Doherty-Kirby A, et al. PEAKS: powerful software for peptide de novo sequencing by tandem mass spectrometry. Rapid Commun Mass Spectrom 2003;17:2337-42.

[80] Carvalho PC, Fischer JSG, Chen EI, Yates JR, Barbosa VC. PatternLab for proteomics: a tool for differential shotgun proteomics. BMC Bioinformatics 2008;9:316.

[81] Carvalho PC, Fischer JSG, Chen EI, Domont GB, Carvalho MGC, Degrave WM, et al. GO Explorer: A gene-ontology tool to aid in the interpretation of shotgun proteomics data. Proteome Sci 2009;7:6.

[82] McCarthy FM, Wang N, Magee GB, Nanduri B, Lawrence ML, Camon EB, et al. AgBase: a functional genomics resource for agriculture. BMC Genomics 2006;7:229.

[83] Altschul SF, Gish W, Miller W, Myers EW, Lipman DJ. Basic local alignment search tool. J Mol Biol 1990;215:403-10.

[84] Ashburner M, Ball CA, Blake JA, Botstein D, Butler H, Cherry JM, et al. Gene ontology: tool for the unification of biology. The Gene Ontology Consortium. Nat Genet 2000;25:25-9.

[85] Görg A, Weiss W, Dunn MJ. Current two-dimensional electrophoresis technology for proteomics. Proteomics 2004;4:3665-85.

[86] Rabilloud T. Use of thiourea to increase the solubility of membrane proteins in two-dimensional electrophoresis. Electrophoresis 1998;19:758-60.

[87] Ishih A, Rodriguez BO, Sano M. Scanning electron microscopic observations of first and third-stage larvae and adults of Angiostrongylus costaricensis. Southeast Asian J Trop Med Public Health 1990;21:568-73.

[88] Carrette O, Burkhard PR, Sanchez JC, Hochstrasser DF. State-of-the-art two-dimensional gel electrophoresis: a key tool of proteomics research. Nat Protoc 2006;1:812-23.

[89] Garcia-Murria MJ, Valero ML, Sanchez del Pino MM. Simple chemical tools to expand the range of proteomics applications. J Proteomics 2011;74:137-50.

[90] Kiel M, Josh P, Jones A, Windon R, Hunt P, Kongsuwan K. Identification of immuno-reactive proteins from a sheep gastrointestinal nematode, Trichostrongylus colubriformis, using two-dimensional electrophoresis and mass spectrometry. Int J Parasitol 2007;37:1419-29.

[91] Weinkopff T, Atwood III JA, Punkosdy GA, Moss D, Weatherly $\mathrm{DB}$, Orlando R, et al. Identification of antigenic Brugia adult worm proteins by peptide mass fingerprinting. J Parasitol 2009;95:1429-35.

[92] Roberts L, Janovy JJ. Foundations in Parasitology. 5th edition. Chicago, USA: Wm.C.Brown Publishers; 1996. p. 659.

[93] Jolodar A, Fischer P, Bergmann S, Buttner DW, Hammerschmidt S, Brattig NW. Molecular cloning of an alpha-enolase from the human filarial parasite Onchocerca volvulus that binds human plasminogen. Biochim Biophys Acta 2003;1627:111-20.

[94] Bernal D, de la Rubia JE, Carrasco-Abad AM, Toledo R, Mas-Coma S, Marcilla A. Identification of enolase as a plasminogen-binding protein in excretory-secretory products of Fasciola hepatica. FEBS Lett 2004;563:203-6.

[95] Ramajo-Hernandez A, Perez-Sanchez R, Ramajo-Martin V, Oleaga A. Schistosoma bovis: plasminogen binding in adults and the identification of plasminogen-binding proteins from the worm tegument. Exp Parasitol 2007;115:83-91.

[96] Perez-Sanchez R, Valero ML, Ramajo-Hernandez A, Siles-Lucas M, Ramajo-Martin V, Oleaga A. A proteomic approach to the identification of tegumental proteins of male and female Schistosoma bovis worms. Mol Biochem Parasitol 2008;161:112-23.

[97] Chiumiento L, Bruschi F. Enzymatic antioxidant systems in helminth parasites. Parasitol Res 2009;105:593-603.

[98] Bell A, Monaghan P, Page AP. Peptidyl-prolyl cis-trans isomerases (immunophilins) and their roles in parasite biochemistry, host-parasite interaction and antiparasitic drug action. Int J Parasitol 2006;36:261-76.

[99] Bridges D, Moorhead GB. 14-3-3 proteins: a number of functions for a numbered protein. Sci STKE 2005;2005:re10.

[100] Siles-Lucas M, Nunes CP, Zaha A, Breijo M. The 14-3-3 protein is secreted by the adult worm of Echinococcus granulosus. Parasite Immunol 2000;22:521-8.

[101] McGonigle S, Loschiavo M, Pearce EJ. 14-3-3 proteins in Schistosoma mansoni; identification of a second epsilon isoform. Int J Parasitol 2002;32:685-93.

[102] Schechtman D, Tarrab-Hazdai R, Arnon R. The 14-3-3 protein as a vaccine candidate against schistosomiasis. Parasite Immunol 2001;23:213-7.

[103] Graeff-Teixeira C, Agostini AA, Camillo-Coura L, Ferreira-da-Cruz MF. Seroepidemiology of abdominal angiostrongyliasis: the standardization of an immunoenzymatic assay and prevalence of antibodies in two localities in southern Brazil. Trop Med Int Health 1997;2:254-60.

[104] Geiger SM, Graeff-Teixeira C, Soboslay PT, Schulz-Key H. Experimental Angiostrongylus costaricensis infection in mice: immunoglobulin isotype responses and parasite-specific antigen recognition after primary low-dose infection. Parasitol Res 1999;85:200-5.

[105] Bender AL, Maurer RL, da Silva MC, Ben R, Terraciano PB, da Silva AC, et al. Eggs and reproductive organs of female Angiostrongylus costaricensis are more intensely recognized by human sera from acute phase in abdominal angiostrongyliasis. Rev Soc Bras Med Trop 2003;36:449-54.

[106] Lehman W, Szent-Gyorgyi AG. Regulation of muscular contraction. Distribution of actin control and myosin control in the animal kingdom. J Gen Physiol 1975;66:1-30.

[107] Otey CA, Kalnoski MH, Lessard JL, Bulinski JC. Immunolocalization of the gamma isoform of nonmuscle actin in cultured cells. J Cell Biol 1986;102:1726-37.

[108] Galletta BJ, Cooper JA. Actin and endocytosis: mechanisms and phylogeny. Curr Opin Cell Biol 2009;21:20-7.

[109] Dell A, Haslam SM, Morris HR, Khoo KH. Immunogenic glycoconjugates implicated in parasitic nematode diseases. Biochim Biophys Acta 1999;1455:353-62.

[110] Zugel U, Kaufmann SH. Role of heat shock proteins in protection from and pathogenesis of infectious diseases. Clin Microbiol Rev 1999;12:19-39.

[111] Lindquist S, Craig EA. The heat-shock proteins. Annu Rev Genet 1988;22:631-77.

[112] Suto R, Srivastava PK. A mechanism for the specific immunogenicity of heat shock protein-chaperoned peptides. Science 1995;269:1585-8. 
[113] Michalak M, Corbett EF, Mesaeli N, Nakamura K, Opas M. Calreticulin: one protein, one gene, many functions. Biochem J 1999;344(Pt 2):281-92.

[114] Ramírez G, Valck C, Ferreira VP, López N, Ferreira A. Extracellular Trypanosoma cruzi calreticulin in the host-parasite interplay. Trends Parasitol 2011;27:115-22.

[115] Park BJ, Lee DG, Yu JR, Jung SK, Choi K, Lee J, et al. Calreticulin, a calcium-binding molecular chaperone, is required for stress response and fertility in Caenorhabditis elegans. Mol Biol Cell 2001;12:2835-45.

[116] Rzepecka J, Rausch S, Klotz C, Schnoller C, Kornprobst T, Hagen J, et al. Calreticulin from the intestinal nematode Heligmosomoides polygyrus is a Th2-skewing protein and interacts with murine scavenger receptor-A. Mol Immunol 2009;46:1109-19.

[117] Kasper G, Brown A, Eberl M, Vallar L, Kieffer N, Berry C, et al. A calreticulin-like molecule from the human hookworm Necator americanus interacts with $\mathrm{C} 1 \mathrm{q}$ and the cytoplasmic signalling domains of some integrins. Parasite Immunol 2001;23:141-52.

[118] Winter AD, McCormack G, Page AP. Protein disulfide isomerase activity is essential for viability and extracellular matrix formation in the nematode Caenorhabditis elegans. Dev Biol 2007;308:449-61.

[119] Larsen PL, Albert PS, Riddle DL. Genes that regulate both development and longevity in Caenorhabditis elegans. Genetics 1995;139:1567-83.
[120] Curran SP, Ruvkun G. Lifespan regulation by evolutionarily conserved genes essential for viability. PLoS Genet 2007;3: e56.

[121] Cassada RC, Russell RL. The dauerlarva, a post-embryonic developmental variant of the nematode Caenorhabditis elegans. Dev Biol 1975;46:326-42.

[122] Klass MR. Aging in the nematode Caenorhabditis elegans: major biological and environmental factors influencing life span. Mech Ageing Dev 1977;6:413-29.

[123] Leffler H, Carlsson S, Hedlund M, Qian Y, Poirier F. Introduction to galectins. Glycoconj J 2004;19:433-40.

[124] Young AR, Meeusen EN. Galectins in parasite infection and allergic inflammation. Glycoconj J 2004;19:601-6.

[125] Dzik JM. Molecules released by helminth parasites involved in host colonization. Acta Biochim Pol 2006;53:33-64.

[126] Hirabayashi J, Kasai K. The family of metazoan metal-independent beta-galactoside-binding lectins: structure, function and molecular evolution. Glycobiology 1993;3:297-304.

[127] Leffler H. Introduction to galectins. Trends Glycosci Glycotechnol 1997;45:9-19.

[128] Arata Y, Akimoto Y, Hirabayashi J, Kasai K, Hirano H. An immunohistochemical study of the 32-kDa galectin (beta-galactoside-binding lectin) in the nematode Caenorhabditis elegans. Histochem J 1996;28:201-7. 